\title{
KAJIAN POTENSI DAN REKOMENDASI DESA LHOKRUKAM BERBASIS DESA WISATA, SEBAGAI ALTERNATIF PEMBANGUNAN KOTA TAPAKTUAN
}

\author{
Resky Rusnanda, Elbi Sepriady, Muhammad Reza \\ E-mail: official_reskyrusnanda@gmail.com
}

\begin{abstract}
South Aceh district with all its natural potencies, is really a high-developed tourism sector area because supported for its geographic. Then Tapaktuan is very well-known with its tourism object such as Tapak Kaki Tuan Tapa which also become the symbol of South Aceh district. It's not the only tourism object priority but also there are still many tourism objects such as like located at Lhokreukam. Whose potential tourism object. Instead, Lhokreukam is still less-developed. That's why this research is conducted to give development strategies toward Lhokreukam due to become rural tourism as the new tourism destination in South Aceh. This research uses SWOT analysis as the method. The research finding is offering the strategic developed recommendation plan as a tourism village. In a result, all the potencies Lhokreukam can be well-developed and sustainable, instead could be other choices tourist destination in South Aceh.
\end{abstract}

Keywords: Tourism, Tourism Region, Tourism Potential, rural Tourism.

\begin{abstract}
Abstrak
Kabupaten aceh selatan dilihat dari potensi alamnya, sektor priwisata sangat produktif untuk dikembangkan, karena didukung oleh letak geografisnya. Tapaktuan sangat dikenal dengan objek wisata tapak kaki tuan tapa yang juga merupakan simbol dari Kabupaten Aceh Selatan. Bukan hanya objek wisata tersebut, banyak objek wisata lainnya yang ada di Tapaktuan menjadi objek wisata andalan salah satunya di desa Lhokreukam yang memiliki potensi wisata yang tinggi. Namun sayangnya pengembangan pariwisata di desa tersebut belum optimal. Oleh sebab itu penelitian ini bertujuan untuk memberikan strategi pengembangan desa lhokreukam menjadi desa wisata sebagai salah satu destinasi wisata baru di Aceh Selatan. Adapaun metode yang di gunakan adalah analisis SWOT. Hasil dari penelitian ini adalah adanya rekomendasi strategi perencanaan pengembangan desa lhokreukam menjadi desa wisata, sehingga semua potensi wisata yang ada di desa tersebut dapat di kembangkan secara optimal dan berkelanjutan, dan menjadi alternatif pilihan berwisata yang ada di kabupaten Aceh Selatan bagi wisatawan.
\end{abstract}

Kata Kunci : Pariwisata, Kawasan Wisata, Potensi Wisata, Desa wisata.

\section{Pendahuluan}

\subsection{Latar Belakang}

Pariwisata merupakan salah satu potensi yang dapat mendukung kemajuan sebuah kota. Keberhasilan pariwisata dikaitkan dengan potensi pariwisata itu sendiri, dimana pariwisata mampu mendorong masyarakat terlibat secara aktif dalam rangka mencapai tujuan yang diinginkan, salah satunya penghasil utama devisa daerah. Kegiatan pariwisata juga memiliki multiplier efect yang cukup besar, artinya, keberhasilan pembangunan sektor pariwisata akan memacu dan mendorong sektor lain untuk berkembang cepat seperti, sektor prindustrian, perdagangan, dan sektor tenaga kerja. Oleh karena itu meningkatnya perkembangan pariwista akan membantu meningkatkan pembangunan kota, karena sektor pariwisata merupakan sektor dibidang ekonomi kreatif.

Kabupaten Aceh Selatan khususnya di Kota Tapaktuan di lihat dari potensi alamnya, sektor pariwisata sangat produktif untuk dikembangkan, karena di dukung oleh letak geografisnya, di tambah lagi dengan kultur masyarakat lokalnya yang kental dan ramah. Dalam pengembangan pariwisata selama ini, tapaktuan sangat dikenal dengan objek wisataTapak Kaki TuanTapa yang juga merupakan simbol dari Kota Tapaktuan. Bukan hanya itu, hampir di setiap kecamatan yang ada di Kabupaten Aceh Selatan memiliki potensi objek wisata yang baik, namun sayangnya, potensi wisata yang ada di kecamatan maupun di desa kurang di manfaatkan dan dikembangkan secara optimal.

Dalam rangka mendukung otonomi desa menjadi desa yang mandiri, maka suatu desa harus dapat 
mengembangkan potensi dan kelestarian alam yang ada di desa tersebut. Maka perlu disadari bahwa keberhasilan suatu desa adalah merupakan partisipasi masyarakat dan langsung akan dirasakan oleh masyarakat itu sendiri.

Merujuk dari potensi alam dan budaya yang ada di kabupaten Aceh Selatan, salah satu desa yang memiliki potensi untuk dikembangkan dibidang pariwisata adalah Desa Lhoukreukam. Desa yang berada di Kecamatan Tapaktuan ini, memiliki potensi alam dan budaya masyarakat lokal yang masih terjaga, memiliki letak geografis yang strategis, memiliki objek wisata pasir setumpuk yang alami, aktivitas pertanian dan perikanan, dan adanya kuliner khas di desa tersebut.

Berdasarkan keseluruhan potensi yang dimiliki oleh desa tersebut, maka strategi pengembangan desa lhoukreukam sangat cocok di kembangkan menjadi desa wisata, dimana suatu desa dikatakan Desa wisata adalah suatu bentuk integrasi antara aksi, akomodasi, dan fasilitas pendukung yang disajikan dalam suatu stuktur kehidupan masyarakat yang menyatu dengan tata cara dan tradisi yang berlaku [1].

\section{Dasar Teori}

\subsection{Pariwisata}

Perkataan pariwisata berasal dari bahasa sansekerta dengan rangkaian suku kata "pari" = banyak, ditambah dengan "wis" = melihat, dan "ata" = tempat. Jadi, pariwisata merupakan terjemahan dari "melihat banyak tempat". Indonesia pada awalnya mengenal pariwisata dengan mempergunakan bahasa asing yaitu "tourism". Perubahan istilah "tourism" menjadi "pariwisata" dipopulerkan ketika dilangsungkan musyawarah nasional [2].

Pengertian pariwisata juga dijelaskan oleh beberapa ahli wisata, diantaranya: pariwisata adalah kegiatan manusia yang melakukan perjalanan ke dan tinggal di daerah tujuan di luar lingkungan kesehariannya [3] . Sedangkan menurut Matheison \& Wall yang dikutip oleh Chris Cooper mengatakan bahwa pariwisata adalah perjalanan sementara ke destinasi di luar rumah dan tempat kerja, aktivitas yang dilakukan selama tinggal di tempat tersebut dengan menggunakan fasilitas yang dibuat untuk memenuhi kebutuhan turis [4].

Dari beberapa definisi tentang pariwisata, Darmaji berbependapat bahwa dari definisi yang dikemukaan oleh para ahli wisata dapat diambil unsur-unsur dari pariwisata itu sendiri, dan unsurunsur tersebut adalah adanya kegiatan mengunjungi suatu tempat, bersifat sementara, ada sesuatu yang ingin dilihat dan dinikmati, dilakukan perseorangan atau kelompok, mencari kesenagan, dan adanya fasilitas di tempat wisata [1].

\subsection{Jenis - Jenis Pariwisata}

Jenis - jenis pariwisata yang ada tidak terlepas dari adanya daya tarik wisata pada suatu daerah, berupa [5] :

- Sumber daya tarik yang bersifat alami, seperti pemandangan alam, lingkungan hidup, flora, fauna, danau, lembah, gunumg, dan lain-lain.

- Sumber daya buatan manusia, seperti peninggalan budaya, arkeologi, candi, arca, dan lain-lain.

- Sumber daya tarik yang bersifat non alami, seperti norma, tradisi, kebiasaan, pandangan hidup, keagamaan, kepercayaan, supranatural, dan lain-lain.

Jenis - jenis pariwisatanya sendiri dapat dikategorikan menjadi 6 kategori, yakni [5]:

1. Wisata Budaya (Cultural Tourism)

2. Wisata Konvensi (Convention Tourism)

3. Wisata Kesehatan (Recuperiational Tourism)

4. Wisata Bahari (Coastal Tourism)

5. Wisata Alam (Rural Tourism)

6. Wisata Kota (Tourism in Urban Area)

7. Wisata Ziarah

\subsection{Pengembangan Pariwisata}

Suatu obyek pariwisata harus memenuhi tiga kriteria agar obyek tersebut diminati pengunjung [6], yaitu :

a. Something to see adalah obyek wisata tersebut harus mempunyai sesuatu yang bisa di lihat atau di jadikan tontonan oleh pengunjung wisata. Dengan kata lain obyek tersebut harus mempunyai daya tarik khusus yang mampu untuk menyedot minat dari wisatawan untuk berkunjung di obyek tersebut.

b. Something to do adalah agar wisatawan yang melakukan pariwisata di sana bisa melakukan sesuatu yang berguna untuk memberikan perasaan senang, bahagia, relax berupa fasilitas rekreasi baik itu arena bermain ataupun tempat makan, terutama makanan khas dari tempat tersebut sehingga mampu membuat wisatawan lebih betah untuk tinggal di sana.

c. Something to buy adalah fasilitas untuk wisatawan berbelanja yang pada umumnya adalah ciri khas atau icon dari daerah tersebut, sehingga bisa dijadikan sebagai buah tangan.

\subsection{Kawasan Pariwisata}

Pengertian kawasan pariwisata ini juga diungkapkan oleh seorang ahli yaitu Inskeep sebagai area yang dikembangkan dengan penyediaan fasilitas dan pelayanan lengkap (untuk rekreasi/relaksasi, pendalaman suatu pengalaman/kesehatan) [7].

Kawasan pariwisata merupakan salah satu bagian dari kawasan budidaya yang ditetapkan dengan 
fungsi utama untuk dibudidayakan atas dasar kondisi dan potensi sumber daya alam, manusia, warisan budaya dan sumber daya buatan. Adapun kriteria kawasan pariwisata menurut Sandy adalah: (1) Pertama, kawasan yang secara teknis dapat digunakan untuk kegiatan pariwisata, tidak menganggu kelestarian budaya, keindahan alam dan lingkungan; (2) Kedua, kawasan yang apabila digunakan untuk kegiatan pariwisata, secara ruang dapat memberikan manfaat, antara lain: meningkatkan devisa dari pariwisata dan mendayagunakan investasi yang ada disekitarnya dan mendorong kegiatan lain yang ada disekitarnya; (3) Ketiga, memiliki kemampuan untuk tetap melestarikan nilai warisan budaya, adat istiadat, kesenian dan mutu keindahan lingkungan alam; (4) Keempat, memiliki kemampuan untuk mendorong dan meningkatkan perkembangan kehidupan ekonomi (multiplier effect) dan sosial budaya; (5) Kelima, memiliki kemampuan berkembang sesuai dengan segmen pasar manca negara maupun domestik [8].

\subsection{Desa Wisata}

Desa wisata adalah suatu bentuk integrasi antara aksi, akomodasi dan fasilitas pendukung yang disajikan dalam suatu stuktur kehidupan masyarakat yang menyatu dengan tata cara dan tradisi yang berlaku. Desa wisata juga merupakan sebuah kawasan pedesaan yangmemiliki beberapa karakteristik khusus untuk menjadi daerah tujuan wisata. di kawasan ini, penduduknya masih memeiliki tradisi dan budaya yang relatif masih asri. Selain itu, beberapa faktor pendukung seperti makanan khas, sistem pertanian dan sistem sosial turutmewarnai sebuah kawasan desa wisata. Diluar faktor-faktor tersebut, alam dan lingkungan yang masih asli dan terjaga merupakan salah satu faktor penting dari sebuah kawasan tujuan wisata [8].

Selain keunikan, kawasan desa wisata juga harus memiliki berbagai fasilitas untuk menunjang sebagai kawasan tujuan wisata. berbagai fasilitas ini akan mempermudah para pengunjung desa wisata dalam melakukan kegiatan wisata. fasilitas-fasilitas yang sebaiknya dimiliki oleh kawasan desa wisata antara lain adalah sarna transportasi, telekomunikasi, kesehatan, dan juga akomodasi. Khusus untuk sarana akomodasi, desa wisata menyediakan sarana penginapan berua pondok wisata (home stay) hingga para pengunjung pun turut merasakan suasana pedesaan yang masih asli [8].

\subsection{Komponen Desa Wisata}

Sebuah desa dapat dikatakan sebagai desa wisata apabila memiliki beberapa komponen yang memiliki potensi untuk pengembangan pariwisata, seperti dijelaskan di bawah ini :
1) Atraksi

Atraksi, atau juga dikenal dengan istilah daya tarik wisata, di suatu desa adalah seluruh kehidupan keseharian penduduk setempat beserta kondisi fisisk lokasi desa yang memungkinkan wisatawan berpartisipasi aktif. Maksud dari pengertian di aytas adalah keaslian kondisi desa tersebut yang menjadi daya tarik sebuah desa wisata, sertamemungkinkan wisatawan melakukan aktivitas-aktivitas yang tidak biasa.

2) Fasilitas

Fasilitas adalah sumber daya yang khusus dibuat karena mutlak dibutuhkan oleh wisatawan dalam aktivitasnya di desa wisata. fasilitas-fasilitas yang dibuat ini dapat memanfaatkan sumber daya yang telah dimiliki desa, atau membuat sesuatu yang baru sesuai kebutuhan namun tidak meninggalkan karakteristik dan keunikan desa tersebut. Beberapa contoh fasilitas desa wisata yang umum adalah sebagai berikut; (1) Pertama, Fasilitas Perkemahan; (2) Kedua, Fasilitas makan-minum; (3) Ketiga, Pusat Jajanan dan Cinderamata; (4) Keempat, Pusat Pengunjung.

3) Aktivitas Wisata

Aktivitas wisata adalah apa yang dikerjakan wisatawan selama keberadaan mereka di daerah tujuan dalam waktu setengah hari sampai bermingguminggu. Beberapa aktivitas wisatayangdapat dilakukan di desa wisata adalah sebagai berikut: (a) menikmati pemandangan, (b) memasak dengan tungku, (c) memancing, (d) Berburu, (e) bersepeda, (f) Hiking dan lain-lain.

4) Pengembangan Umum

Pengembangan umum adalah sebuah upaya yang dilakukan berdasarkan perencanaan untuk menciptakan sebuah daerah tujuan wisata yang memberikan pelayanan terbaik bagi wisatawan. Beberapa upaya pengembangan umum yang utama yaitu [8]:

- Pembagian Zona/Area.

Pembagian zona dapat dilakukan dengan membagi zona berdasarkan fungsinya, misalnya zona atraksi, zona fasilitas, zona akomodasi, dan zona asli (zona yg tidak dibangun untuk kepentingan pariwisata).

- Pengelolaan Pengunjung.

Pengelolaan pengunjung adalah pengaturan pola aktivitas, alur kedatangan hingga kepulangan wisatawan, dan lain-lain. Beberapa teknik dalam pengelolaan pengunjung adalah ; (1) Pembatasan terhadap jumlah area yangdigunakan; (2) Penyebaran area yang digunakan bagi wisatawan; (3) pemusatan Area; (4)Pembatasan lama tinggal; (5) Pemanfaatan area secara bergantian/musiman; (6) Pembatasan jumlah pengunjung; (7) Penentuan harga masuk; (8) Pengaturan arus pengunjung. Dengan menerapkan teknik-teknik pengelolaan pengunjung dengan baik, 
tentunya dapat memberikan manfaat terhadap aspek dalam desa.

- Pelayanan Interpretasi

Pelayanan interpretasi adalah sebuah komnukiasi yang betujun untuk menyampaikkan informasi melalui berbagai media penyampaian baik maupun tidak langsung. Beberapa tekni interpretasi yaitu : (1) Brosur dan selebaran; (2) Pemandu wisata; (3) Perjalanan wisata yang dipandu; (4) Tourist Information Centre; (4) Kuesioner.

\subsection{Kriteria Desa Wisata}

Berdasakan dari tujuan mengenai desa wisata maka dalam menentukan kriteria sebuah desa menjadi desa wisata adalah :

1) Atraksi wisata; yaitu semua yang mencangkup alam, budaya dan hasil ciptaan manusia. Atraksi yang dipilih adalah yang paling menarikdan atraktif di desa.

2) Jarak Tempuh; adalah jarak tempuh dari kawasan terutama tempat tinggan wisatawan dan juga jarak tempuh dari ibukota provinsi dan jarak dari ibukota kabupaten.

3) Besaran Desa; menyangkut masalah-masalah jumlah rumah, jumlah penduduk, karakteristik dan luas wilayah desa. Kriteria ini berkaitan dengan daya dukung kepariwisataan pada suatu desa.

4) Sistem Kepercayaan dan kemasyaratan; merupakan aspek penting mengingat adanya aturan-aturan yang khusus pada komunitas sebuah desa.

5) Ketersediaan infratuktur; meliputi fasilitas dan pelayanan transportasi, listrik, air bersih, drainase, telpon, dan sebagainya.

Masing-masing kriteria digunakan untuk melihat karakteristik utama suatu desa untuk kemudian menentukan apakah suatu desa akan menjadi desa dengan tipe berhenti sejenak, tipe one day trip atau tipe tinggal inap.

\section{Metoda Penelitian}

Jenis penelitian adalah deskriptif kualitatif, adapun yang menjadi variabel penelitian adalah sesuai dengan konsep desa wisata yakni dari segi atraksi wisata, amenitas, aksesibilitas, besaran desa, sistem kepercayaan masyarakat. dimana hasil pengamatan dari keseluruhan variabel, di analisis dengan menggunakan Matrik SWOT. Dimana analisis SWOT memberikan suatu pandangan dasar tentang kondisi yang dihadapai sehingga di dapatkan strategi yang tepat dan rekomendasi yang baik.

\section{Desa Lhokreukam}

\subsection{Kondisi Geografis dan Ekonomi}

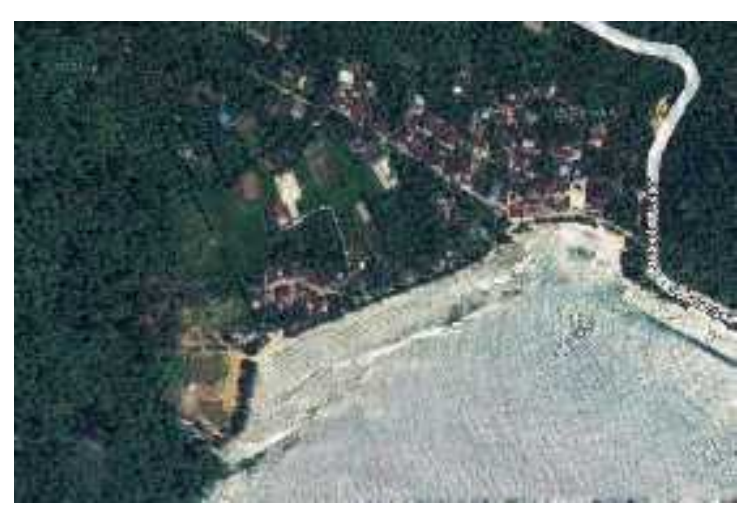

Gambar 1. Peta lokasi DesaLhokreukam

Sumber: Google map

Desa Lhokreukam terletak dikawasan lembah, terdiri dari $158 \mathrm{KK}$, dengan jumlah rumah 153 rumah. Dari segi ekonomi, mayoritas penduduk di desa ini dapat dilihat dari aspek mata pencaharian, dimana mata pencaharian penduduk local adalah mengandalakan sector pertanian dan kelautan.

\subsection{Potensi Wisata di Desa Lhokreukam}

Desa lhokreukam memiliki potensi wisata yang cukup tinggi untuk dikembangkan, karena di dukung oleh letak geografi dari desa tersebut. Lhokreukam memiliki pantai yang cukup panjang dengan hamparan pasir yang masih asri. Objek wisata lainnya yang dapat kita temui di Desa Lhokreukam adalah Pantai Pasir Setumpuk yang menawarkan suasana pantai yang berbeda dan tersembunyi karena terletak jauh dari pemukiman penduduk.

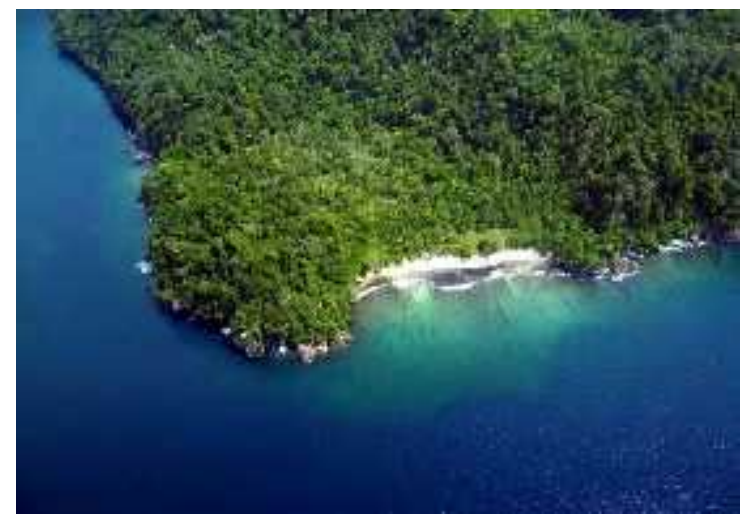

Gambar 2. Objek Wisata Pasir Setumpuk Sumber : Google 


\section{Hasil dan Pembhasan}

\subsection{Analisis atraksi dan fasilitas}

Untuk mengetahui lokasi desa wisata dilakukan dengan mengidentifikasi atraksi-atraksi wisata yang terdapat di daerah tersebut.

Tabel 1. Atraksi - atraksi wisata di Desa Lhokreukam

\begin{tabular}{|c|c|c|c|}
\hline $\mathrm{N}_{2}$ & Dus Yiata & 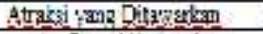 & 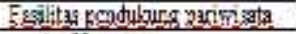 \\
\hline 1 & 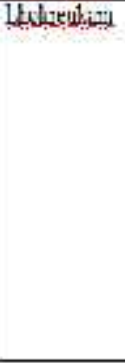 & 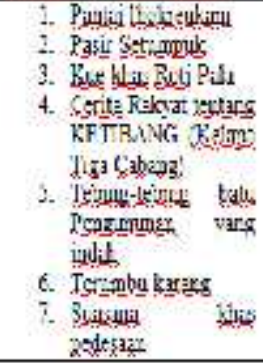 & 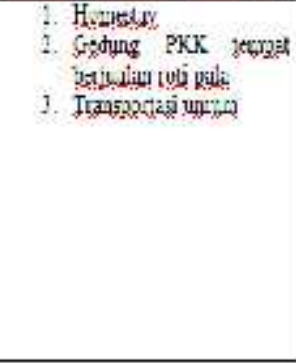 \\
\hline
\end{tabular}

Sumber : Peneliti, 2015

\subsection{Analisis SWOT}

Analisis SWOT dimaksudkan untuk memperjelas semua kekuatan dan kelemahan yang dapat di identifikasi guna memberikan rekomendasi pengembangan berdasarkan potensi-potensi yang tersedia.

a. Analisis Faktor Internal dan eksternal dengan menggunakan skala likert

Tabel 2. Faktor Internal

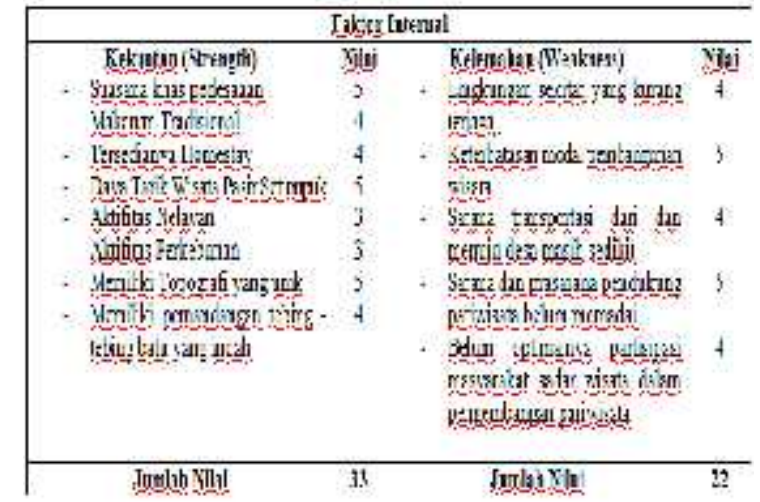

Sumber : Peneliti

Analisis faktor-faktor eksternal meliputi faktor peluang dan ancaman. Adapun nilai dari masingmasing faktor tersebut adalah untuk faktor peluang (O) mendapatkan nilai 28 dan untuk faktor ancaman (T) dengan nilai 11. Dari nilai yang diperoleh tampak jelas bahwa untuk aderah Aceh Selatan khususnya desa wisata menjadi potennsial untuk dikembangkan salah satunya di Desa Lhokreukam. b. Analisis dengan Menggunakan Matrix SWOT.

Analisis ini adalah analisis matrix SWOT guna menentukan alternative strategi. Matrix ini disusun oleh faktor-faktor kekuatan (S), kelemahan (W), peluang (O) dan ancaman (T) yang merupakan penyusunan faktor-faktor strategis analisis internal dan eksternal.

Tabel. 2. Analisis Matrix SWOT

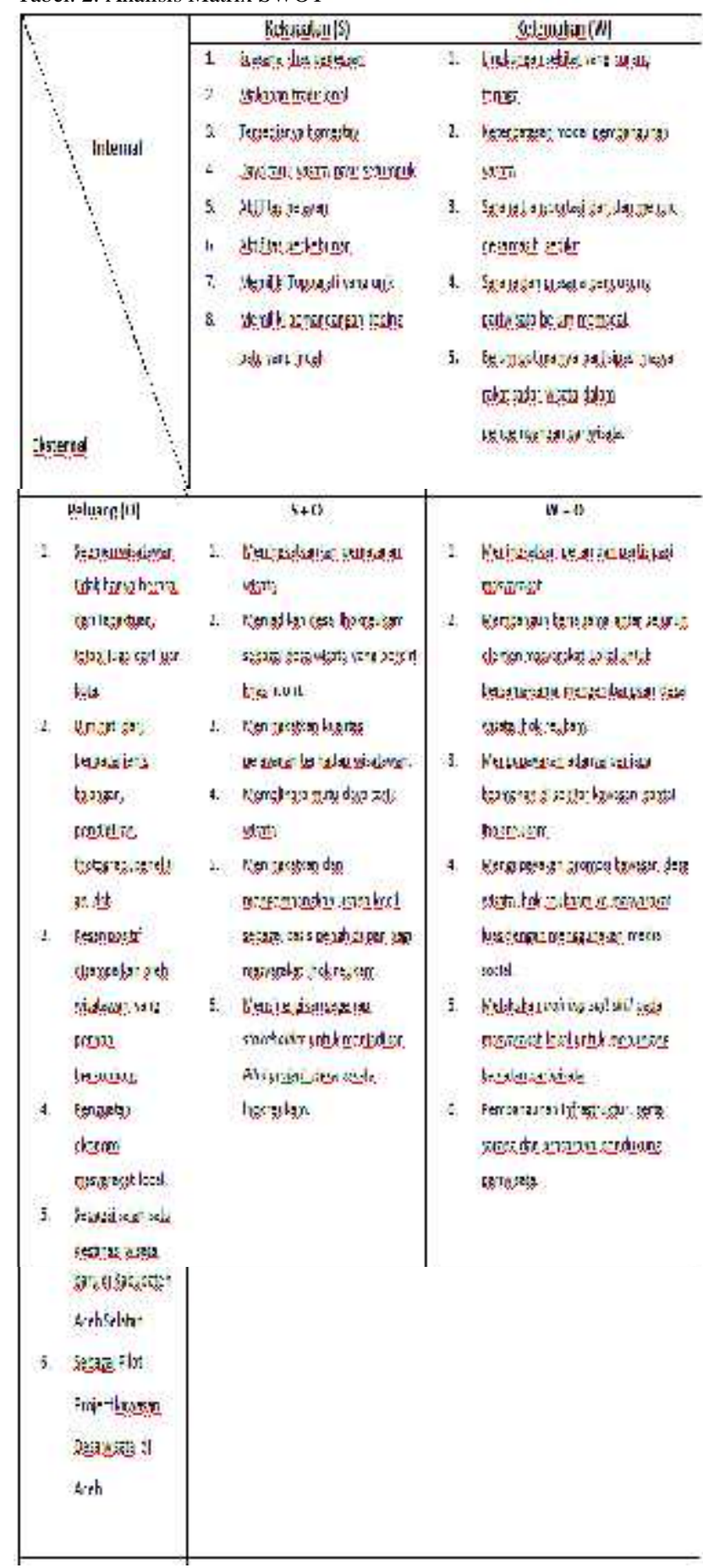




\begin{tabular}{|c|c|c|}
\hline arropan & 5.7 & $7+\pi$ \\
\hline 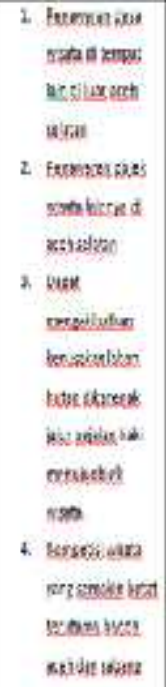 & 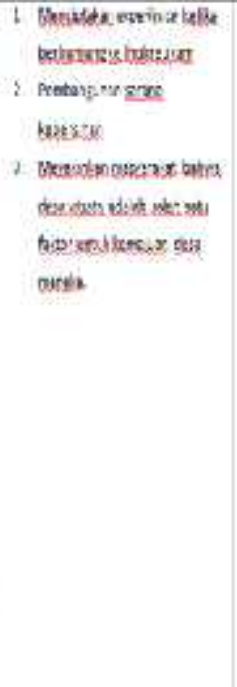 & 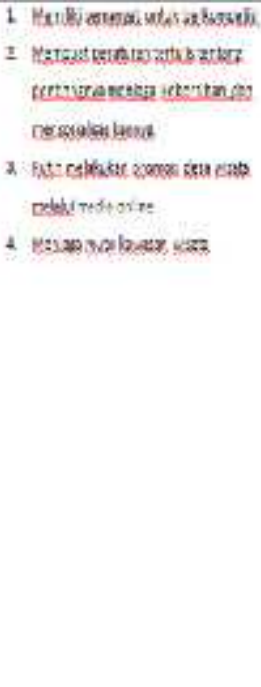 \\
\hline
\end{tabular}

Hasil dari analisa matrix SWOT dapat dirumuskan strategi SO yang merupakan perpaduan antara faktor kekuatan dan peluang dengan alternative sebagai berikut : 1) meningkatkan pemasaran wisata. 2) Menjadikan desa lhoreukam sebagai desa wisata yang berciri khas. 3) Meningkatkan kualitas pelayanan terhadap wisatawan. 4) Memelihara mutu daya tarirk wisata. 5) meningkatkan dan mengembangkan usaha kecil sebagai basis penghidupan bagi masyarakat lhokreukam. 6) Mensinergikan segenap stakeholder untuk menjadikan pilot project desa wisata lhokreukam.

Strategi WO merupakan perpaduan dari faktor kelemahan dan peluang memberikan alternative strategi sebagai berikut : 1) Meningkatkan peran dan partisipasi masyarakat. 2) Membangun kerja sama antar seluruh elemen masyarakat okal untuk mengembangkan desa wisata lhokreukam. 3) Mengupayakan adanya penjaga keamanan di sekitar lokasi. 4) Melakukan promosi kawasan desa wisata lhokreukam. Melakukan training soft skill pada masayrakat local. 5) pembangunan infrastuktur, serta sara dan prasarana pendukung pariwisata.

Strategi ST yang merupakan perpaduan faktor kekuatan dan ancaman memberikan alternative strategi yaitu 1) Menciptakan pengalaman yang baik ketika berkunjung ke lhokreukam. 2) pembangunan sarana kerbersihan. 3) meyakinkan masyarakat bahwa desa wisata adalah salah satu faktor pendukung kemajuan desa mereka.

Startegi yang terakhir adalah strategi WT yang merupakan petimbangan faktor kelemahan dan ancaman dengan cara rutin melakukan promosi desa wisata, menjaga mutu kawasan wisata.

\section{Kesimpulan dan Rekomendasi}

Dari hasil penelitian di atas dapat disimpulkan bahwa pengembangan pariwisata pedesaan di desa lhokreukam masih mengandalkan daya tarik alam, yaitu pantai pesisir, pasir setumpuk dan wisata bahari bawah lautnya dan sesuai dengan teori mengenai desa wisata, desa ini sangat cocok untuk dikembangkan sebagai desa wisata berdasarkan komponen dari desa wisata itu sendiri.

Adapun rekomendasi masterplan perencanaan desa wisata lhokreukam adalah sebagaiberikut :

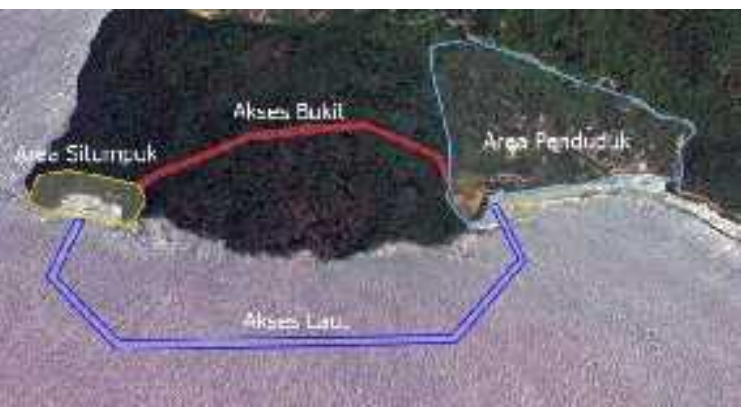

Gambar 3. Letak Geografis Desa Lhokrukam

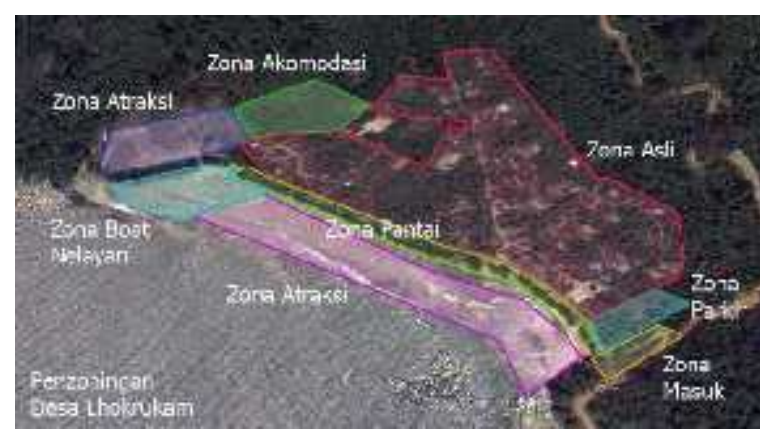

Gambar 4. Rekomendasi Penzonaan Kawasan

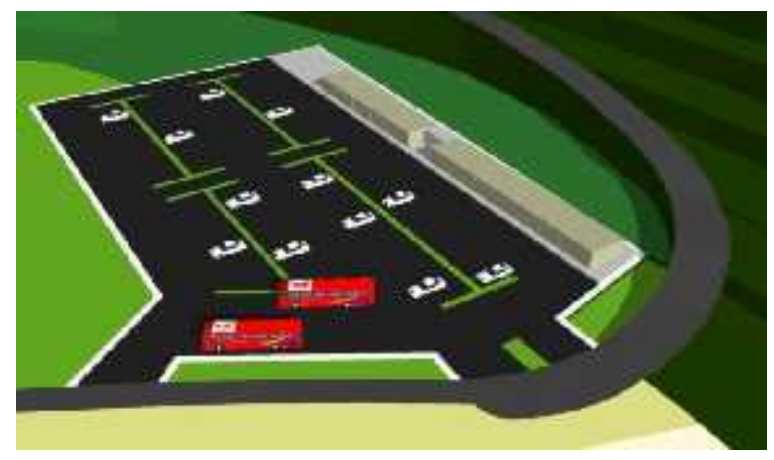

Gambar 5. Rekomendasi area parker 


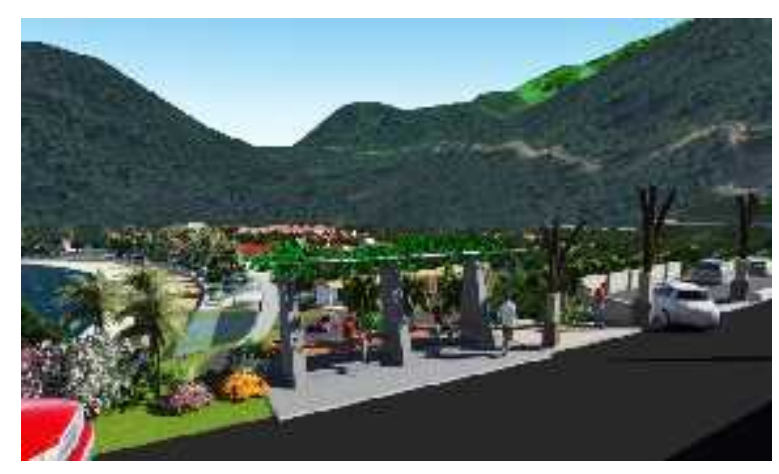

Gambar 6. Rekomendasi rencana pintu gerbang

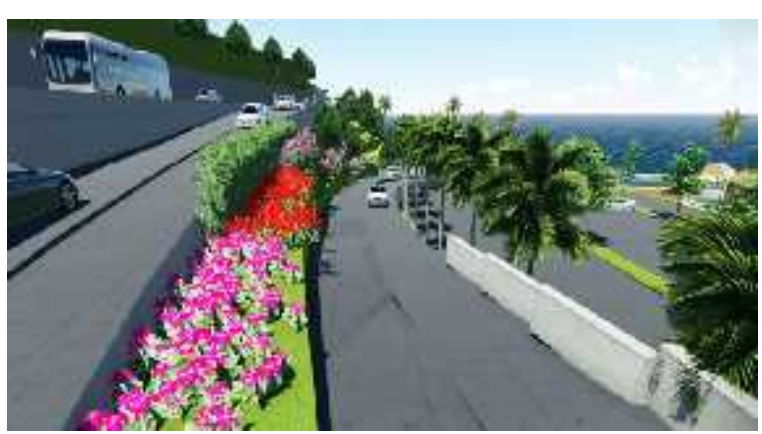

Gambar 7. Rekomendasi akses jalan menuju desa

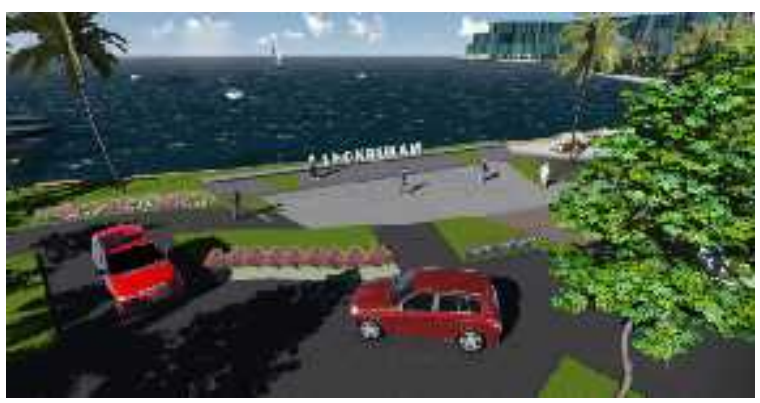

Gambar 8. Rekomendasi landmark desa

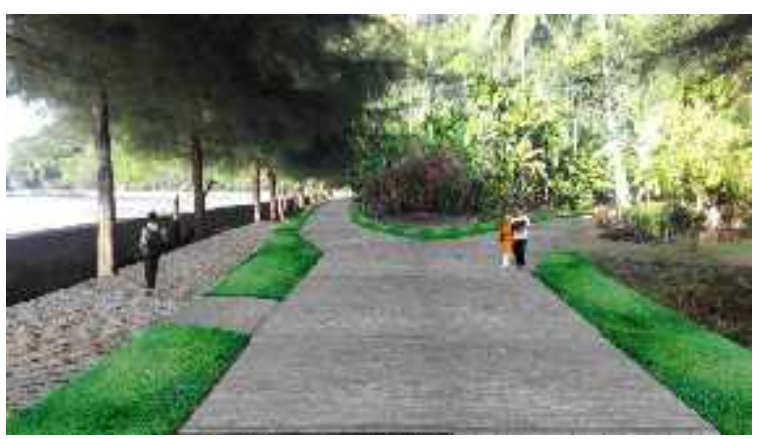

Gambar 9. Rekomendasi Jalan setapak dalam desa

\section{Daftar Pustaka}

[1] Nuryanti, Wiendu. Concept, perspective and Challenges Tourism, Gajah Mada University Press, Yogyakarta, 1993.

[2] Darmaji, R.S. Istilah-istilah Dunia Pariwisata, PT. Pradnya, 1992.
[3] Richardson, john and martin Fluker, Understanding and managing Tourism, Australia : Person Education, 2004.

[4] Cooper, et. Al, Tourism Principle and pratice, 3nd ed, Perntice hall, Newyork, 2005.

[5] Sukawi, Mencari Potensi Kota Lama Semarang,Enclosure Volume 7 No. 1, 2008

[6] Yoeti, Oka, Perencanaan dan Pengembangan Pariwisata, Jakarta : PT. Pradnya Paramita, 2002.

[7] Inskeep, Edward, Tourism Planning: An Integrated and sustainable Approach, Van Nostrand Reinhold, New York, Inc, 1991.

[8] Sastropoetro. Santoso, Partisipasi, Komunikasi Dan Persuasi Dan Disiplin DalamPembangunan Nasional, Bandung, 1998. 